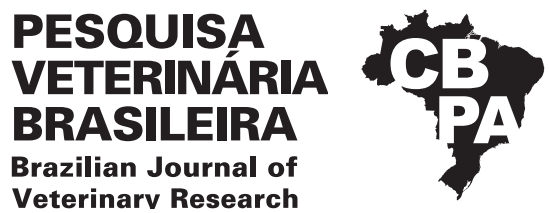

Pesq. Vet. Bras. 41:e06868, 2021

DOI: $10.1590 / 1678-5150-P V B-6868$

Original Article

Veterinarv Research

ISSN 0100-736X (Print)

ISSN 1678-5150 (Online)

\title{
Histopathology and microscopic morphology of protozoan and metazoan parasites of free ranging armadillos in Brazil ${ }^{1}$
}

\author{
Alexandre Arenales ${ }^{2}$, Estevam G.L. Hoppe ${ }^{3}$, Chris Gardiner ${ }^{4}$, Juliana P.S. $\mathrm{Mol}^{2}$, \\ Karin Werther ${ }^{3}$ and Renato L. Santos ${ }^{2 *}$ (I)
}

\begin{abstract}
Arenales A., Hoppe E.G.L., Gardiner C., Mol J.P.S., Werther K. \& Santos R.L. 2021. Histopathology and microscopic morphology of protozoan and metazoan parasites of free ranging armadillos in Brazil. Pesquisa Veterinária Brasileira 41:e06868, 2021. Escola de Veterinária, Universidade Federal de Minas Gerais, Campus Pampulha, Av. Pres. Antônio Carlos 6627, São Luiz, Belo Horizonte, MG 31270-901, Brazil. E-mail: rsantos@vet.ufmg.br

This study assessed microscopic morphology of protozoan and metazoan parasites, as well as parasite-associated histopathologic changes in five Brazilian free-ranging armadillos. Three armadillos had intra sarcolemmal cysts of Sarcocystis sp. in skeletal muscles without microscopic changes. One Dasypus novemcinctus was found parasitized with a nematode morphologically compatible with an oxyurid in the small intestine. One Dasypus sp. had neutrophilic enteritis associated with adult and larval stages of Strongyloides sp. and one D. novemcinctus had multiple embryonated eggs free in the lumen of the small intestine with mild neutrophilic enteritis. These findings represent a contribution for expanding our knowledge on parasitic diseases of armadillos.
\end{abstract}

Index term: Histopathology, microscopic morphology, protozoan, metazoan, parasites, armadillos, Brazil, Dasypus novemcinctus, Sarcocystis sp., Strongyloides sp., parasitism.

RESUMO.- [Histopatologia e morfologia microscópica de parasitos protozoários e metazoários de tatus de vida livre no Brasil.] Este estudo avaliou a morfologia microscópica de parasitos protozoários e metazoários, bem como lesões associadas ao parasitismo em cinco tatus de vida livre no Brasil. Três tatus tinham cistos de Sarcocystis sp. Intra-sarcolemal em músculos esqueléticos sem alterações microscópicas. Um Dasypus novemcinctus estava parasitado com um nematodo morfologicamente compatível com oxiurideo no intestino delgado. Um Dasypus sp. apresentou enterite neutrofílica associada com estágios larvais de Strongyloides sp. e um $D$. novemcinctus apresentou múltiplos ovos embrionados livres no

\footnotetext{
${ }^{1}$ Received on February 18, 2021.

Accepted for publication on March 3, 2021.

${ }^{2}$ Departamento de Clínica e Cirurgia Veterinária, Escola de Veterinária, Universidade Federal de Minas Gerais (UFMG), Campus Pampulha, Av. Pres. Antônio Carlos 6627, São Luiz, Belo Horizonte, MG 31270-901, Brazil. *Corresponding author: rsantos@vet.ufmg.br

${ }^{3}$ Departamento de Patologia, Reprodução e Saúde Única, Faculdade de Ciências Agrárias e Veterinárias, Universidade Estadual Paulista "Júlio de Mesquita Filho" (Unesp), Via de Acesso Prof. Paulo Donato Castellane s/n, Vila Industrial, Jaboticabal, SP 14884-900, Brazil.

${ }^{4}$ Veterinary Pathology Service, Joint Pathology Center, 606 Stephen Sitter Ave, Silver Spring, MD 20910, USA.
}

lúmen do intestino delgado, associado a enterite neutrofílica discreta. Estes achados representam uma contribuição para a expansão do conhecimento sobre doenças parasitárias de tatus.

TERMOS DE INDEXAÇÃO: Histopatologia, morfologia microscópica, parasitos, protozoários, metazoários, tatus, Brasil, Dasypus novemcinctus, Sarcocystis sp., Strongyloides sp., parasitismo.

\section{INTRODUCTION}

Armadillos are mammals belonging to the Xenarthra superorder and the Cingulata order. These animals are naturally found only in the American continent, including 21 species of which 11 are registered in Brazil (Medri et al. 2011). Some of those species are a conservation concern, including the giant armadillo (Priodontes maximus) and the Southern long-nosed armadillo (Dasypus hybridus), both having decreasing populations so they are considered vulnerable (Abba \& Gonzalez 2014) or near threatened (Anacleto et al. 2014) according to the International Union for Conservation of Nature (IUCN) red list, respectively. Most of the animals included in this study are Dasypus novemcinctus (nine-banded armadillo), which are considered of least concern according to the IUCN.

A better understanding of host-pathogen interactions is a key element in wildlife conservation (Worbesen 2005). In spite 
of recent studies on diseases of other Xenarthra species such as anteaters (Arenales et al. 2020a) and sloths (Arenales et al. $2020 \mathrm{~b}$ ), there are a few studies focused on pathologic changes associated with protozoan and metazoan parasites and parasitic diseases of armadillos. Previous reports described Leishmania (Lainson \& Shaw 1989), Sarcocystis neurona (Cheadle et al. 2001, Tanhauser et al. 2001), Mathevotaenia (Gomes et al. 2012, Ríos et al. 2016) and Angiostrongylus cantonensis (Dalton et al. 2017) affecting armadillos. In addition, there is a survey in Texas (Chandler 1946), and a few reports on helminths in Brazilian mammals that include parasites from armadillos (Vicente et al. 1997, Lux Hoppe \& Nascimento 2007, Lux Hoppe et al. 2009). However, histopathological findings are usually absent in those previous reports. Therefore, the focus of this study was to describe histopathological changes associated with protozoan and metazoan parasites in five free ranging armadillos from Brazil.

\section{MATERIALS AND METHODS}

Five free ranging armadillos were referred to the wildlife pathology service at the "Faculdade de Ciências Agrárias e Veterinárias", "Universidade Estadual Paulista 'Júlio de Mesquita Filho'"' (Unesp, Jaboticabal/SP, Brazil) for necropsy, from 1994 to 2017. Several tissue samples from internal organs were sampled, including lungs (5/5), liver (5/5), skeletal muscle (4/5), kidney (4/5), spleen (3/5), heart (3/5), stomach $(3 / 5)$, small intestine (3/5), trachea (3/5), esophagus $(3 / 5)$, tongue $(2 / 5)$, testes $(2 / 5)$, brain $(2 / 5)$, cerebelum $(2 / 5)$, urinary bladder $(2 / 5)$, ovary $(1 / 5)$, skin $(1 / 5)$, thymus $(1 / 5)$, lymph node $(1 / 5)$, pancreas $(1 / 5)$, and adrenal (1/5). Samples were fixed in $10 \%$ buffered formalin, processed for paraffin embedding, sectioned at $4-\mu \mathrm{m}$, and stained with hematoxylin and eosin (HE). Tissues samples with morphologically detectable Sarcocystis sp. were processed for DNA extraction from paraffin embedded tissue samples and subjected to PCR amplification of rRNA 18s sequences as previously described by Harrus et al. (2011).

\section{RESULTS}

Table 1 summarizes the findings observed in the armadillos included in this study. Animals 2, 4, and 5 had occasional intra sarcolemmal cysts morphologically compatible with Sarcocystis sp. in skeletal muscles, including the tongue and esophagus. These cysts were not associated with any microscopic change. Importantly, cysts of Sarcocystis sp. had two distinct microscopic morphologic patterns: cysts observed in the tongue of Animal 2 had a thick capsule with a brush-like outer layer, containing large bradyzoites with lower densities and an abundant matrix (Fig.1). In contrast, cysts of Sarcocystis sp. observed in Animals 4 and 5 had a thinner and smoother capsule, without the brushlike outer layer, smaller bradyzoites, representing a denser population within scarce matrix (Fig.2 and 3). The attempt

Table 1. Characterization of armadillos included in this study and microscopic changes associated with protozoan and metazoans

\begin{tabular}{|c|c|c|c|c|}
\hline Animal & Host species & Sex & Age & Histopathology \\
\hline 1 & Dasypus novemcinctus & M & Adult & Small intestine: lumenal embryonated eggs; no lesions associated \\
\hline 2 & Dasypus novemcinctus & $\mathrm{F}$ & Adult & Tongue: intrasarcolemmal Sarcocystis sp. cysts (brush-like outer capsule); no lesions associated \\
\hline 3 & Dasypus sp.* & $\mathrm{F}$ & Young & $\begin{array}{l}\text { Small intestine: neutrophilic diffuse and mild enteritis with intralesional Strongyloides sp. } \\
\text { (adults and larvae stages) }\end{array}$ \\
\hline 4 & Dasypus sp.* & $\mathrm{F}$ & Adult & Esophagus and skeletal muscle: intrasarcolemmal Sarcocystis sp. cysts; no lesions associated \\
\hline 5 & Dasypus novemcinctus & M & Adult & $\begin{array}{l}\text { Duodenum: lumenal oxyurid nematode, tongue: intrasarcolemmal Sarcocystis sp. cysts; no } \\
\text { lesions associated }\end{array}$ \\
\hline
\end{tabular}

* Species not identified; NR = not reported.
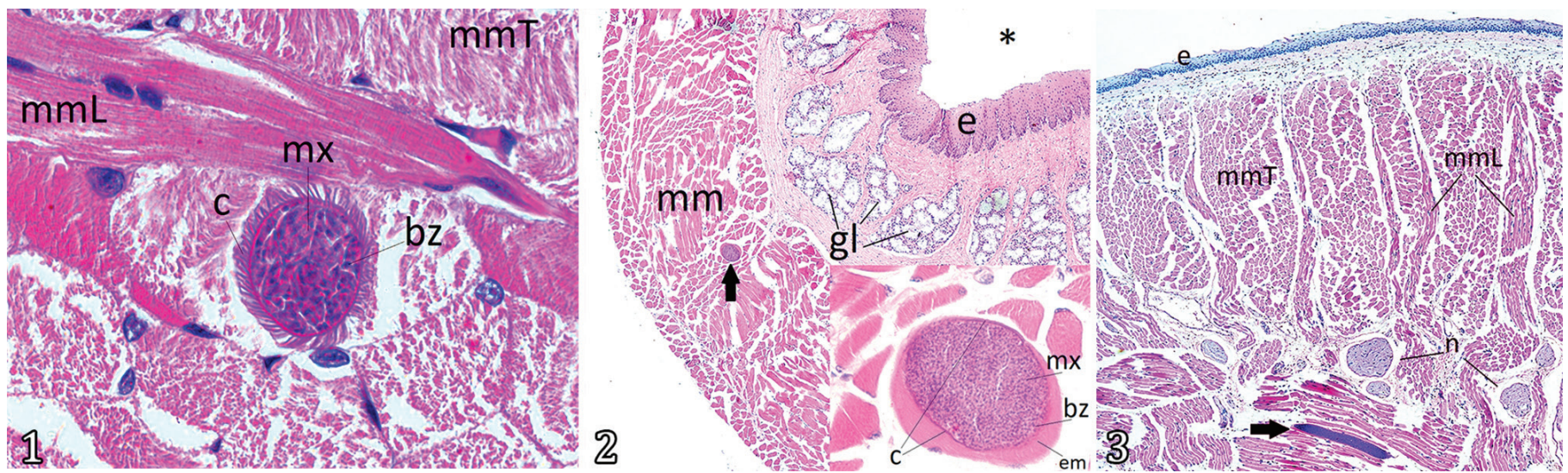

Fig.1-3. Armadillos with intrasarcolemmal Sarcocystis sp. cysts with two distinct morphologic appearance. (1) Dasypus novemcinctus, Animal 2. Tongue, skeletal muscle cells in transversal ( $\mathrm{mmT}$ ) and longitudinal ( $\mathrm{mmL}$ ) sections. Sarcolemma containing a Sarcocytis sp. cyst with thick and brush-like outer capsule (c) with large and low density bradyzoites (bz), and abundant matrix (mx). HE, obj.100x. (2) Dasypus sp., Animal 4. Esophagus; muscular esophageal layer $(\mathrm{mm})$ with a cyst of Sarcocystis sp. (arrow); esophageal lumen $(*)$, epithelium (e) and esophageal glands (gl). HE, obj.5x. Inset: higher magnification of a Sarcocytis sp. cyst. Notice a different morphological aspect when compared to Figure 1: thinner and smoother capsule (c), without brush appearance, smaller and higher density bradyzoites (bz) and fewer matrix (mx) amounts. HE, obj.40x. (3) Dasypus novemcinctus, Animal 5. Tongue. Epithelium (e) skeletal muscle cells in transversal (mmT) and longitudinal ( $\mathrm{mmL}$ ) sections and nerves (n); Sarcocytis sp. cyst (arrow) in the sarcolemma, with morphological features similar to Figure 2. HE, obj.5x. 
for amplification of rRNA 18s sequences by PCR (Harrus et al. 2011) for a phylogenetic identification of these parasites was not successful in any of the samples.

Animal 5 (Dasypus novemcinctus) had sections of a nematode within the duodenal lumen. These parasites measured approximately $200 \mu \mathrm{m}$ in diameter, with a thick cuticle, thin hypodermis, large lateral alae, platymyarian musculature, and intestine lined by columnar and uninuclear cells with a prominent brush border on the apical side (Fig.4-5). These parasites were surrounded by abundant cellular debris with minimal to mild neutrophilic infiltrate. The parasite was morphologically identified as an oxyurid nematode.

In the small intestine of one armadillo (Animal 3) there were larval and adult stages of Strongyloides sp. Adult parasites measured approximately $30 \mu \mathrm{m}$ in diameter, and had two cross sections of the genital tract and a distinct intestine (Fig.6). Additionally, in Strongyloides sp. infections only females parasitized hosts. Adult parasites were coiled and located within the superficial epithelium associated with minimal to mild neutrophilic inflammatory infiltrate in the adjacent lamina propria, characterizing mild acute enteritis (Fig.7). Early stage developing eggs were also observed on the superficial mucosa among cellular debris (Fig.8). In addition, multiple 10 to $15 \mu \mathrm{m}$ in diameter metazoan embryonated eggs (Fig.9) were free in the small intestine lumen of Animal 1, with a mild neutrophilic enteritis.
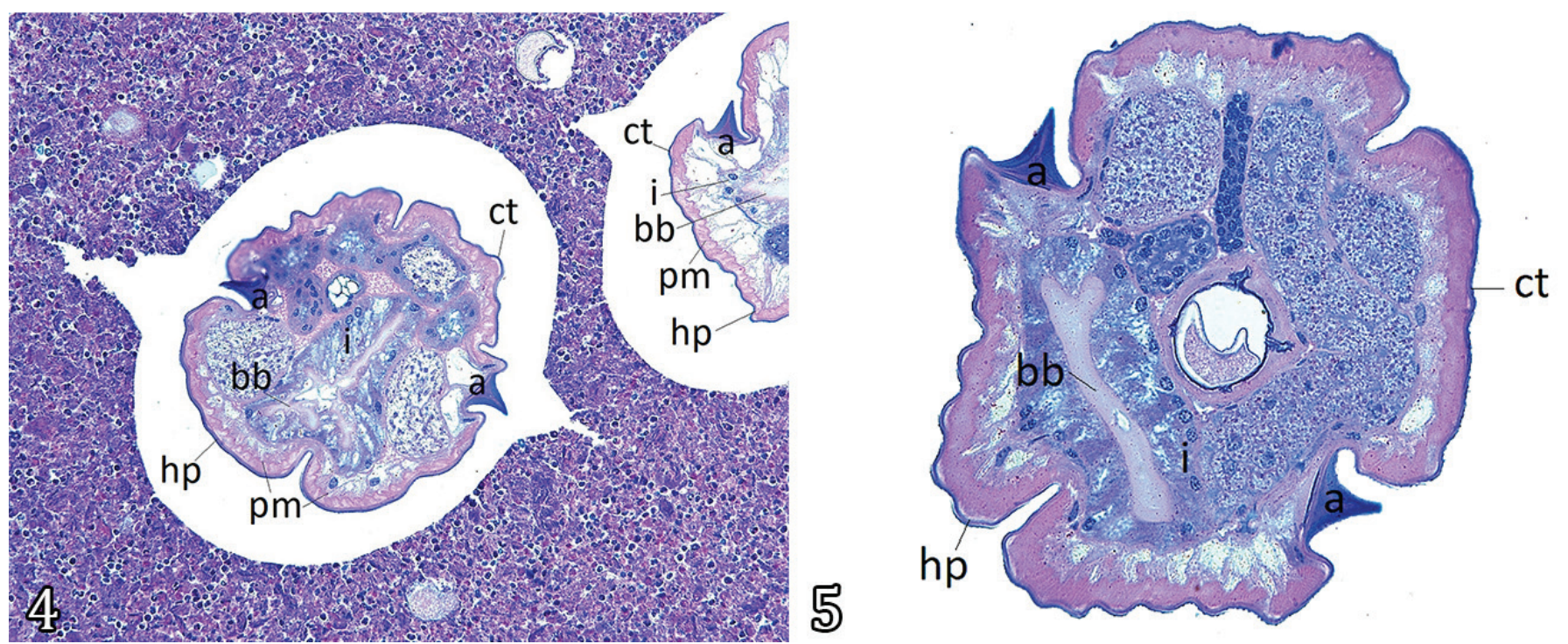

Fig.4-5. Dasypus novemcinctus, Animal 5. Cross sections of an oxyurid nematode in the intestinal lumen, surrounded by debri and bacteria, measuring approximately $200 \mu \mathrm{m}$ in diameter, with a thick cuticle (ct), thin hypodermis (hp), lateral alae (a), platymyarian musculature (pm), characterized by large and separated muscle fibers, parallel to the cuticle; and an intestine (i) lined by columnar and uninuclear cells with prominent brush border (bb). (4) Two transversal sections of nematode surrounded by abundant cellular debris with scarce neutrophils. HE, obj.10x. (5) Transversal cut section of nematode in a different portion. HE, obj.20x.
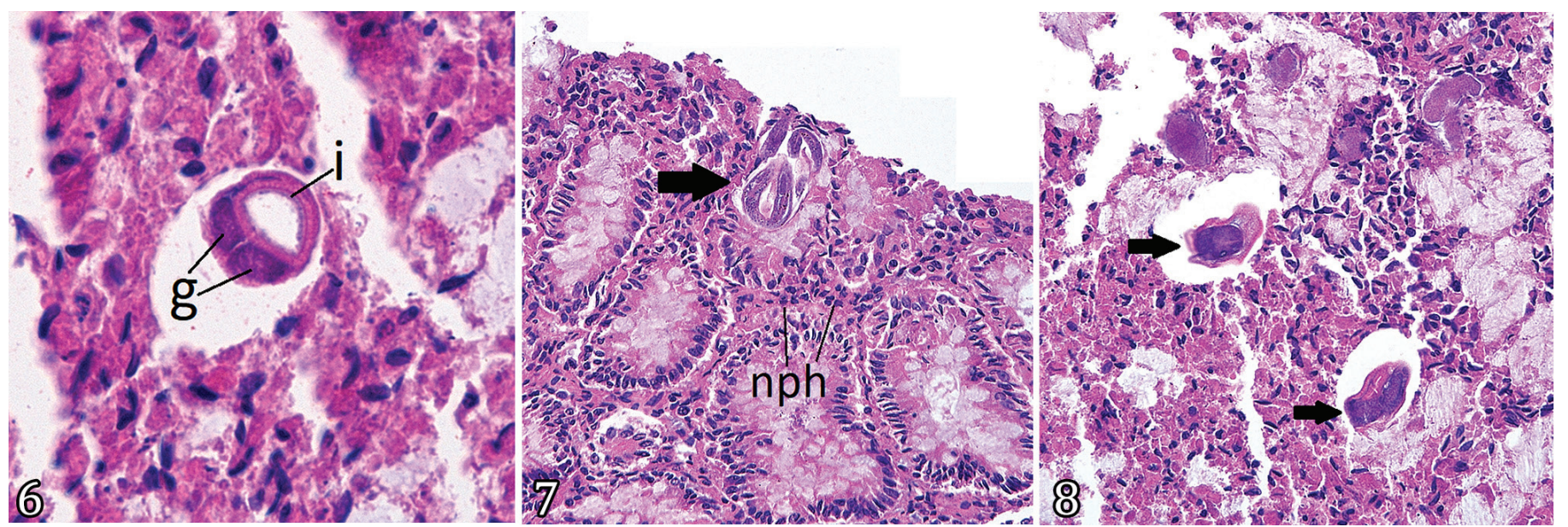

Fig.6-8. Dasypus sp., Animal 3. Small intestine, adult female nematodes morphologically compatible with Strongyloides sp., measuring approximately $30 \mu \mathrm{m}$ in diameter. (6) Transversal section; intestine (i) and genital tracts (g) characterizing a female. HE, obj.40x. (7) Longitudinal section; nematode coiled (arrow) within the superficial mucosa with minimal neutrophilic (nph) inflammatory infiltrate in the lamina propria, characterizing a mild acute enteritis. HE, obj.20x. (8) Early stage eggs (arrows) on the superficial mucosa among cellular debris. HE, obj.10x. 


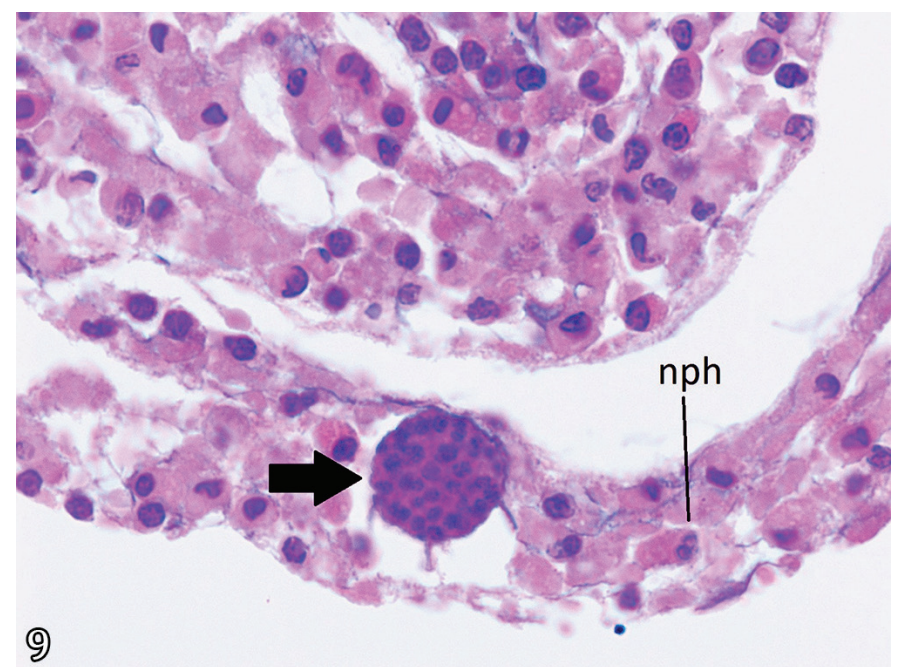

Fig.9. Dasypus novemcinctus, Animal 1. Small intestine, lumen containing free embryonated eggs (arrow), which are multilobulated and contains multicellular structures, measuring approximately $20 \times 10 \mu \mathrm{m}$ with scant neutrophils ( $\mathrm{nph}$ ) in the laminae propria. HE, obj.100x.

\section{DISCUSSION}

This study described microscopic changes associated with protozoan and metazoan parasites in free-ranging armadillos. Parasite specimens from Animal 5 were not available for parasitological identification and the parasites could not be identified morphologically based on histological sections. Oxyurid nematodes are common in many species of both invertebrate and vertebrate animals (Hugot et al. 1996, Carreno 2014), although it has not been previously reported in armadillos. However, identification of these parasites in this study was based solely on histologic features, which did not allow for a conclusive parasitological diagnosis. Finding of neutrophils and debris associated with this parasite suggests a parasiteelicited enteritis, which could be associated with clinical disease. However, oxyurid nematodes do not usually elicit a pathological response in their hosts (Roberts \& Janovy 2009).

Strongyloides helminths were observed in Animal 3 (Dasypus sp.), associated with a neutrophilic enteritis. To the best of our knowledge this is the first report of a microscopic diagnosis of parasitic enteritis in an armadillo. Two Species of Strongyloides parasites have been described in Dasypus novemcinctus, i.e., Strongyloides ratti and Strongyloides dasypodis (Lux Hoppe \& Nascimento 2007, Lux Hoppe et al. 2009) but specific identification of the parasite based on histological morphology was not possible in this case. Additionally, Strongyloides were the probable source of the embryonated eggs observed in Animal 1 (Gardiner \& Poynton 1999).

In regard to Sarcocystis sp., as described in this study, an early report described two species based on histological morphology: Sarcocystis dasypi (small and more density bradyzoites with thinner capsule) and Sarcocystis diminuta (thicker capsule and large and fewer bradyzoites) (Lindsay et al. 1996). Although this morphologic distinction is interesting under an anatomic pathology point of view, it is not possible to identify Sarcocystis species based on morphology in histological sections (Dubey et al. 2016). Sarcocystis sp. are found in the skeletal muscle of intermediate hosts as a terminal asexual stage (Dubey et al. 2016). It has been described in armadillos, with $75 \%$ of D. novemcinctus (nine-band armadillo) in Brazil infected with Sarcocystis sp. (Antunes et al. 2012). In fact, more recent studies with molecular techniques demonstrated that nine-band armadillos are intermediate hosts for Sarcocystis neurona in the United States (Cheadle et al. 2001, Tanhauser et al. 2001). Therefore, considering the occurrence of equine protozoal myeloencephalitis in Brazil (Masri et al. 1992, Paixão et al. 2007, Henker et al. 2020), it reasonable to hypothesize that Brazilian armadillos may act as intermediate hosts for $S$. neurona. Thus, detection of $S$. neurona in armadillos in Brazil would be an interesting topic of future investigations. Unfortunately PCR amplification of rRNA 18s failed in these samples, which may have been influenced by over-fixation since these were archive samples subjected to variable (often prolonged) fixation periods.

\section{CONCLUSION}

This study demonstrated parasites in free-ranging armadillos in Brazil,as well as parasite-associated histopathologic changes, which is a relevant contribution for expanding our knowledge on parasitic diseases of armadillos.

Acknowledgements.- Work in R.L.S. lab is supported by "Conselho Nacional de Desenvolvimento Científico e Tecnológico" (CNPq), Brazil, "Fundação de Amparo a Pesquisa do Estado de Minas Gerais" (FAPEMIG), and “Coordenação de Aperfeiçoamento de Pessoal de Nível Superior" (CAPES), Brazil. R.L.S. has a fellowship from CNPq, Brazil.

Conflict of interest statement.- The authors declare no conflict of interest.

\section{REFERENCES}

Abba A.M. \& Gonzalez E. 2014. Dasypus hybridus, Southern long-nosed armadillo. The IUCN Red List of Threatened Species. e.T6288A47440329. <https://dx.doi.org/10.2305/IUCN.UK.2014-1.RLTS.T6288A47440329.en>

Anacleto T.C.S., Miranda F., Medri I., Cuellar E., Abba A.M. \& Superina M. 2014. Priodontes maximus, giant armadillo. The IUCN Red List of Threatened Species. e.T18144A47442343. <https://dx.doi.org/10.2305/IUCN. UK.2014-1.RLTS.T18144A47442343.en>

Antunes J.M.A.P., Pereira F.E.L., Demoner L.C., Martins I.V.F., Zanini M.S. \& Deps P. 2012. Sarcocystis spp. in nine-banded armadillos (Dasypus novemcinctus) from Brazil. Revta Port. Ciênc. Vet. 111(581/582):119-120.

Arenales A., Gardiner C.H., Miranda F.R., Dutra K.S., Oliveira A.R., Mol J.P.S., Costa M.E.L.T., Tinoco H.P., Coelho C.M., Silva R.O.S., Pinto H.A., Hoppe E.G.L., Werther K. \& Santos R.L. 2020a. Pathology of free-ranging and captive Brazilian anteaters. J. Comp. Pathol. 180:55-68. <https://dx.doi. org/10.1016/j.jcpa.2020.08.007> <PMid:33222875>

Arenales A., Silva F.L., Miranda F., Guedes P.E.B., Werther K., Costa M.E.L.T., Tinoco H.P., Coelho C.M. \& Santos R.L. 2020b. Pathologic findings in 36 sloths from Brazil. J. Zoo Wildl. Med. 51(3):672-677. <https://dx.doi. org/10.1638/2020-0002>

Carreno R.A. 2014. The systematics and evolution of pinworms (Nematoda: Oxyurida: Thelastomatoidea) from invertebrates. J. Parasitol. 100(5):553560. <https://dx.doi.org/10.1645/14-529.1><PMid:24842083>

Chandler A.C. 1946. Helminths of armadillos, Dasypus novemcinctus, in Eastern Texas. J. Parasitol. 32(3):237-241. <https://dx.doi.org/10.2307/3272675> <PMid:20990866>

Cheadle M.A., Tanhauserb S.M., Damea J.B., Selon D.C., Hines M., Ginn P.E., MacKaya R.J. \& Greinerb E.C. 2001. The nine-banded armadillo (Dasypus novemcinctus) is an intermediate host for Sarcocystis neurona. Int. J. Parasitol. 
31(4):330-335.<https://dx.doi.org/10.1016/s0020-7519(01)00177-1> $<$ PMid:11306111>

Dalton M.F., Fenton H., Cleveland C.A., Elsmo E.J. \& Yabsley M.J. 2017. Eosinophilic meningoencephalitis associated with rat lungworm (Angiostrongylus cantonensis) migration in two nine-banded armadillos (Dasypus novemcinctus) and an opossum (Didelphis virginiana) in the southeastern United States. Int. J. Parasitol. Parasites Wildl. 6(2):131-134. <https://dx.doi.org/10.1016/j.ijppaw.2017.05.004> <PMid:28626635>

Dubey J.P., Calero-Bernal R. \& Rosenthal B.M. 2016. General biology, p.1108. In: Dubey J.P., Calero-Bernal R. \& Rosenthal B.M. (Eds), Sarcocystis of animals and humans. CRC Press, Boca Raton.

Gardiner C.H. \& Poynton S.L. 1999. An atlas of metazoan parasites in animal tissues. Armed Forces Institute of Pathology, Washington DC, p.1-3.

Gomes S.N., Pesenti T.C. \& Muller G. 2012. Parasitismo de Mathevotaenia sp. (Cestoda: Anplocephalidae) e Centrorhynchus sp. (Acanthocephala: Centrorhynchidae) em Dasypus novemcinctus (Mammalia: Xenarthra) no Brasil. Neotrop. Helminthol. 6(2):287-290.

Harrus S., Perlman-Avrahami A., Mumcuoglu K.Y., Morick D., Eyal O. \& Baneth G. 2011. Molecular detection of Ehrlichia canis, Anaplasma bovis, Anaplasma platys, Candidatus Midichloria mitochondrii and Babesia canisvogeli in ticks from Israel. Clin. Microbiol. Infect. 17(3):459-463. <https://dx.doi. org/10.1111/j.1469-0691.2010.03316.x><PMid:20636417>

Henker L.C., Bandinelli M.B., Andrade C.P., Bianchi M.V., Sonne L., Driemeier D., Soares J.F. \& Pavarini S.P. 2020. Pathological, immunohistochemical, and molecular findings of equine protozoal myeloencephalitis due to Sarcocystis neurona infection in Brazilian horses. Trop. Anim. Health Prod. 52(6):3809-3817. <https://dx.doi.org/10.1007/s11250-020-02419-y> <PMid:33011934>

Hugot J.P., Gardner L. \& Morand S. 1996. The Enterobiinae fam. nov. (Nematoda, Oxyurida), parasites of primates and rodents. Int. J. Parasitol. 26(2):147-159. <https://dx.doi.org/10.1016/0020-7519(95)00108-5><PMid:8690538>

Lainson R. \& Shaw J.J. 1989. Leishmania (Viannia) naiffi sp. n., a parasite of the armadillo, Dasypus novemcinctus (L.) in Amazonian Brazil. Ann. Parasitol. Hum. Comp. 64(1):3-9. <https://dx.doi.org/10.1051/parasite/19896413> $<$ PMid:2930120>

Lindsay D.S., Mckown R., Upton S.J., McAllister C.T., Toivio-Kinnucan M.A., Veatch J.K. \& Blagburn B.L. 1996. Prevalence and identity of Sarcocystis infections in armadillos (Dasypus novemcinctus). J. Parasitol. 82(3):518-520. <PMid:8636867>
Lux Hoppe E.G. \& Nascimento A.A. 2007. Natural infection of gastrointestinal nematodes in long-nosed armadillos Dasypus novemcinctus Linnaeus, 1758 from Pantanal wetlands, Aquidauana sub-region, Mato Grosso do Sul State, with the description of Hadrostrongylus speciosum n. gen. et n. sp. (Molineidae: Anoplostrongylinae). Vet. Parasitol. 144(1/2):87-92. <https://dx.doi.org/10.1016/j.vetpar.2006.09.028>

Lux Hoppe E.G., Araújo de Lima R.C., Tebaldi J.H., Athayde A.C.R. \& Nascimento A.A. 2009. Helminthological records of six-banded Armadillos Euphractus sexcinctus (Linnaeus, 1758) from the Brazilian semi-arid region, Patos county, Paraíba state, including new morphological data on Trichohelix tuberculata (Parona and Stossich, 1901) Ortlepp, 1922 and proposal of Hadrostrongylus ransomi nov. comb. Braz. J. Biol. 69(2):423-428. <https:// dx.doi.org/10.1590/s1519-69842009000200027>

Masri M.D., Alda J.L. \& Dubey J.P. 1992. Sarcocystis neurona-associated ataxia in horses in Brazil. Vet. Parasitol. 44(3/4):311-314. <https://dx.doi. org/10.1016/0304-4017(92)90128-v>

Medri I.M., Mourão G.M. \& Rodrigues F.H.G. 2011. Ordem Cingulata, p.7590. In: Reis N.R., Paracchi A.L., Pedro W.A. \& Lima I.P. (Eds), Mamíferos do Brasil. Londrina.

Paixão T.A., Rêgo I.O.P. \& Santos R.L. 2007. Anti-Sarcocystis neurona immunostaining associated with equine protozoal myeloencephalitis in Brazil. Ciência Rural 37(6)1820-1823. <https://dx.doi.org/10.1590/ S0103-84782007000600052>

Ríos T.A., Ezquiaga M.C., Abba A.M. \& Navone G.T. 2016. Intestinal parasites of Tolypeutes matacus, the most frequently consumed armadillo in the Chaco region. Int. J. Parasitol. Parasites Wildl. 5(3):254-257. <https:// dx.doi.org/10.1016/j.ijppaw.2016.08.001>

Roberts L.S. \& Janovy J.J. 2009. Gerald D. Schimidt and Larry S Roberts' Foundations of parasitology. McGraw-Hill, New York. 701p.

Tanhauser S.M., Cheadle M.A., Massey E.T., Mayer B.A., Schroedter D.E., Dame J.B., Greiner E.C. \& MacKay R.J. 2001. The nine-banded armadillo (Dasypus novemcinctus) is naturally infected with Sarcocystis neurona. Int. J. Parasitol. 31(4):325-329. <https://dx.doi.org/10.1016/s0020-7519(01)00178-3> $<$ PMid:11306110>

Vicente J.J., Rodrigues H.O., Gomes D.C. \& Pinto R.M. 1997. Nematóides do Brasil. Parte V: nematóides de mamíferos. Revta Bras. Zool. 14(Supl.1):1-452. <https://dx.doi.org/10.1590/S0101-81751997000500001>

Worbesen G.A. 2005. Essentials of Wild Animals Diseases. Wiley-Blackwell, Ames, p.3-10. 